p.155

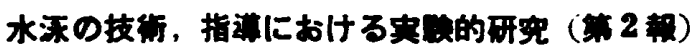
都立富土高校 $\mathrm{O}$ 荒 木 東京教育大学 丹下 保夫 東京教育大学附属高校 中 村 知 和光学園布旅茂治

他 学校体育研究同志全

旧来の文部省指導要領に示されてある，学習系統に問 题があることは昨年も指摘したが，昨年に続いての罢検

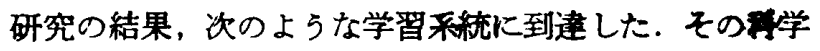
的曼つけけについては共同研究の中村氏が解明した。

以下呼吸法を核とした学習系統を述べる。

\section{I 呼吸法の模漗}

(1) 陸上での練習一いきをロにためておき一度に「パ

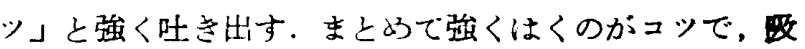
らことは考えない。

(2) プールに入つてから一腰又は胸位の深さに入り， 立位（水の中に圙を入れないで）のまま練習．安定さす ためにするらの四肢みたいに睦に手をおくとよい．

(3) 次第に身体を沈めて一(2)と同様なことを㭽い草の

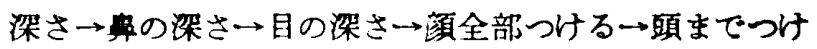
るといらようにたんんたんと全身を水に入れながら，水面 からロが出る時「ハッッと強く吐く. 顔, 頭を入れてや るのを20回以上重点的に行う. 学習困奞な子どすには シャワーの利用を考える。

(4)手をのばして一顔をつけ手腕を前にのばして手は 動かさず顔を起しながら「ハツ」と行なら．手首，指の 力な拔き楽にして行な5。

(5) 呼吸之手の協底一(4)の動作に踠のかきを加え, か き始めたら顔を出してハッ上一度に吐く. 手のかきは楽 に，動作はゆつくりと大きく行な5.

(1) 呼吸と篎行一(bの動作で腕のかきによつて少し進 んたら，ゆつくり步行しながら行なら．呼吸と腕のかき が中心で動作は大きくゆつくりと。

(7) 呼吸と浮き沈み一水にもぐり䏠で水をかきながら 浮いて出る. 顔が水面にきたときに一度にハッと吐く. 吐くタイミングを間違えないように注意する。功作はゆ つくりとし水面には示くらいまで出るようにする.

(8) ケンケン歩さと呼喛一手と呼吸がうをくいつたら， ケンケン (左右不問) で前に身体をのばすよ5にしてす ナみながら行なう，呼吸と腕のかきをらまく合せるよう
にする. 一度けつてのぴ，けつた足は最初余りのばさな いで，すぐにまげて立ち，たんたた両足とものばして行 ならよらにする。ケンケンと呼吸を連続でできるように する.

(9)呼吸と践のび一凮，腹に大きな球をかかえたよう なつもりで，やや丸くなつた智で両足で践り，浮いた ら少し待ち、腕をかいて呼吸する，跖つたあとしばらく 静かにして待つのがコッで，呼吸するまでは死んたよら にダラリとしている．最初は一跻りごとに立つがたんだ ん連続して行なう．遠くにのびるようにする。

\section{II 呼昨法から泳法へ}

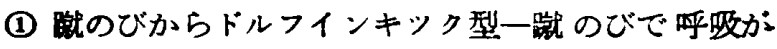
連挬したら，足が少し沈んでくるので足の沈みを防ぐた めに, 兩足をそろえて脱力し, 足首から先を静かに動か す、滕をまけていよが進もうとし強く打つてはいけな い. 足の讴むのを防ぐのがねらいである．足に気をとら れて呼吸を忘れないこと。

(2) ドル平泳法一呼吸をマスターしながら，次第に進 めるように腕のかきを注意し（少し横にかく，斜後ろ へ）足は沈まないようにゆつくり打つ. 早く進もうとし たり，早く手をかいたり，足を多く打つで沈いけ怢い. そして回数を少なくして，のびを十分とり距離をのばす ようにする。

$100 \mathrm{~m}$ くらいこの泳ぎが出来るまでは他の泳法をやら ないで、泳点 (呼吸) が楽になるように努力する.全身 の脱力と手足の動作をゆつくりやるのがュッである.

以上のような新しい学習系統について㬰践してきた が，その細部の资料は布施氏が，その科学的襄づげにつ いては中村氏が述べた。

この学習の中で時間をかけて練習する項目は，(4)，(1) (8であり，それによつてドル平泳法に容易に到達できる か，小学校低学年においては結果的には(1)から順次学習 する方が，楽にしかも早く泳げるよらになる。

この秝でいえることは，乎吸法中心に学習して，一 つ一つの技術をえの上に積みあげていくので，水をのん だりむせたりする人が少なく安全で，しかも著しい進歩 を示すことである.

今後更に発達年令に応した系統と，学習内容を明らか にし，宾の国民のための体育教材とするために，研究と 実践の積み重ねをしていきたいと考えている。 